JURNAL PENDIDIKAN, p-ISSN 2715-095X, e-ISSN 2686-5041

Volume 30, No.2, Juli 2021 (341-352)

Online: http://journal.univetbantara.ac.id/index.php/jp

\title{
Peningkatan Kemampuan Menulis Teks Eksplanasi dengan Menggunakan Media Audio Visual Pada Siswa Kelas XI MIPA 1 SMA N 1 Gemolong
}

\begin{abstract}
Jumadi
SMA Negeri 1 Gemolong, Kabupaten Sragen, E-mail: djumadie002@gmail.com

Received: May 28, 2021

Accepted: Juni 10, 2021

Online Published: Juni 26, 2021

Abstrak: Tujuan penelitian ini adalah untuk meningkatkan kualitas proses dan kemampuan menulis teks eksplanasi siswa melalui penggunaan media audio visual dan dengan penerapan Media Audio Visual untuk meningkatkan kemampuan menulis teks eksplanasi pada peserta didik kelas XI MIPA 1 SMA Negeri 1 Gemolong. Penelitian iniadalah penelitian tindakan kelas yang dilaksanakan dalam dua .siklus dengan dua pertemuan yang terdiri dari perencanaan, tindakan pengamatan, dan refleksi. Subyek penelitian adalah peserta didik kelas XI MIPA 1 SMA Negeri 1 Gemolong pada semester I tahun pelajaran 2018-2019. Sumber data diperoleh dari guru, peserta didik, tempat, dan peristiwa berlangsungnya aktivitas pembelajaran dan dokumentasi. Teknik dan alat pengumpulan data menggunakan observasi, kuesoner, dan wawancara. Hasil penelitian menunjukkan adanya peningkatan motivasi dan tingkat kemampuan menulis teks eksplanasi pada siswa. Rata-rata skor teks eksplanasi siswa skor teks adalah 74,611 dengan tingkat keberhasilan 69,23\%. Pada periode penjelasan teks akhir siswa rata-rata skor adalah 84,42 dengan tingkat keberhasilan $88,46 \%$. Kata, media audio visual. Berdasarkan hasil observasi kinerja guru juga mengalami peningkatan sehingga hal tersebut mempengaruhi kemampuan menulis teks eksplanasi pada peserta didik kelas XI MIPA 1 SMA Negeri 1 Gemolong. Berdasarkan fhasil penelitian di atas dapat disimpulkan bahwa penerapan Media Audio Visual dapat meningkatkan motivasi menulis teks eksplanasi peserta didik Kelas XI MIPA 1 SMA Negeri Gemolong Tahun Pelajaran 2018-2019.
\end{abstract}

Kata-kata Kunci: keterampilan menulis, teks eksplanasi

\section{Improving Explanation Text Writing Ability Using Audio Visual Media In Class XI MIPA 1 SMA Negeri 1 Gemolong}

\author{
Jumadi \\ SMA Negeri 1 Gemolong, Kabupaten Sragen,E-mail: djumadie002@gmail.com
}

\begin{abstract}
The purpose of this study was to improve the quality of the process and the ability to write explanatory texts of students through the use of Audio Visual media and with the aplication of Audio Visual media to improve the sbility to write explanatory texts in students of class XI MIPA 1 SMA Negeri 1 Gemolong. Thisresearch ia a classroom action researc conducted in two cycles with two meetings consisting of planning, observation, and reflection. The research subjects were students of class XI MIPA 1 SMA Negeri 1 Gemolongin the first semester of the 2018 - 2019 school year. The data sources were obtained from teachers, students, places, and events where learning activites and documentation took place. Data collection techniques and tools used observation, questionnaires, and interviews. The results
\end{abstract}


showed that there waas an increase in students, motivation and level of ability to write explanatory texts. The average scor of the students explanatory texts score was 74,611 with a succes rate of $69,23 \%$. In the period of explanatory of the final text, the average score of students was 84,42 with a succes rate of $88,46 \%$. Based on the results of observations, teacher performance has also increased so that it affects the ability to write explanatory texts fo students in class XI MIPA 1 SMA Negeri 1 Gemolong. Based on the results of the research above, it can be concluded that the aplication of "Audio Visuak Media" can increase the motivation to write axplanatory texts for class XI MIPA 1 SMA Negeri 1 Gemolong Academic Year 2018-2019.

Keywords: writing skills, explanatory text, audio-visual media

\section{Pendahuluan}

Pendidikan merupakan proses pemindahan ilmu pengetahuan, nilai, dan melalui lembaga-lembaga pendidikan baik formal maupun non-formal (Dwi Siswoyo dkk. 2007: 19) Berdasarkan Permendikbud No. 103 tahun 2014 pasal 2 ayat I tentang Proses Pembelajaran Pada Pendidikan Dasar dan Pendidikan Menengah bahwa pembelajaran dilaksanakan berbasis aktivitas dengan karakteristik interaktif, inspiratif, kontekstual, kolaboratif, menyenangkan, menantang dan memotivasi serta memberikan ruang yang cukup bagi prakarsa, kreativitas dan kemandirian peserta didik sesuai dengan bakat, minat,kemampuan, dan perkembangan fisik serta psikologis peserta didik. Bahasa Indonesia di dalam proses pembelajaran merupakan salah satu mata pelajaran wajib yang daajarkanpada tingkat pendidikan dasar, menengah, sampai jenjang perguruan tinggi. Kompetensiberbahasa sendiri terdiri dari empat aspek berbahasa, yaitu keterampilan menyimak,keterampilanberbicara, keterampilan membaca dan keterampilan menulis. Bagi perserta didik, aspek ketrampilan menulislah yang dianggap paling sulit. Kesulitan dalam menulis, Byrne (dalam Sumardi:23) mengkategorikan tiga problem yang membuat ketrampilan menulis menjadi sulit untuk dikuasai yaitu permasalahan kebahasaan, pengetahuan, konten.Selain itu juga dikarenakan kurangnya minat atau kurangnya pemahaman dalam menulis.

Berdasarkan hasil survei sebelum pelaksanaan siklus pada hari selasa tanggal 12 April 2018 menunjukkan bahwa ketrampilan dan motivasi menulis siswa masih sangat rendah. Hal terscbut dapat dilihat dari hasil angket dan keseluruhan siswa, sebanyak 18 siswa, atau $46,15 \%$ mengalami kesulitan paling berat pada aspek menulis dalam pembelajaran bahasa Indonesia, Sisanya memilih berbicara, menyimak, dan membaca. Hasil penilaian dari lembar penilaian menulis teks yang diberikan oleh guru, Jumlah Siswa yang hasil menulis teks pada rentang nilai 55-59 tidak ada yang nilainya masuk pada dalam rentang nilai 65-69 ada 15 orang. Yang nilanya masuk dalam rentang nilai 70-74 ada 3 rentang nilai 55-59 tidak ada. yang nilainya masuk pada rentang nilai 60-64 ada 11 orang,. Yang nilainya masuk orang .Yangnilainya masuk dalam rentang nilai 75-79 ada 5 orang.Sedangkan dari rentang nilai 80 keatas 2 siswa. Aspek yang menjadi dasar penilaian guru adalah isi, organisast isi, originalitas, pemilihan kosakata dan pengembangan bahasa. 
Dengan demikian masih ada $80,77 \%$ siswa yang masih di bawah KKM yaitu sebanyak 70 siswa.

Berdasarkan data tersebut nyatanya ketrampilan menulis belum mencapai batas minimal. Karena memang ketrampilan menulis dianggap sebagai ketrampilan berbahasa yang paling kompleks. Menulis dianggap kompleks karena dalam menulis banyak hal - hal yang harus diperhatikan. Hal-hal yang harus diperhatikan dalam menulis di antaranya: tema,dan kalimat. Akhdiah,dkk (dalam Jumadi:3) mengatakan bahwa kemampuan menulis merupakan kemampuan yang kompleks. Sedangkan Alex dan Achmad (dalam Jumadi:3). mengungkapkan menulis merupakan suatu kegiatan untuk menciptakan suatu catatan atau informasi pada suatu media dengan menggunakan aksara. Maka dari itu, tidak heran jika peserta didik menganggap bahwa materi ketrampilan menulis menjadi momok. Sehingga hasil pembelajaran ketrampilan menulis masih banyak di bawah kriteria ketuntasan minimal (KKM). Rendahnya hasil belajar Bahasa Indonesia khususnya materi "Menulis Teks Eksplanasi" disebabkan kurangnya efektifitas proses pembelajaran di kelas (Suwarto, 2017). Faktor lain adalah rendahnya motivasi belajar peserta didik. Indikasi adanya kurang keaktifan peserta didik yaitu peserta didik takut bertanya, penyajian materi kurang menarik (Suwarto, 2009). Hal tersebut disebabkann bahan hanya buku pegangan, kurangnya fasilitas kelas atau LCD yang sudah rusak dan keterbatasa kemampuan guru dalam menerapkan media pembelajaran. Untuk mengetahui kemampuan dalam menulis teks sehingga ada peningkatan kualitas proses belajar Bahasa Indonesia maka diperlukan peningkatan kualitas para pendidik. Sebenarnya bukan hanya penyusunan kembali kurikulum dalam bentuk RPP yang lebih sempurna melainkan pembenahan media yang sesuai dengan memperhatikan mata pelajaran, fasilitasn, dan kondisi peserta didik sebagai subek penelitian yakni motivasi belajar yang dimiliki, minat ketekunan, dan karakteristik. Sehingga semakin baik media yang digunakan maka makin efektif dalam pencapaian tujuan pembelajaran yang dimaksud.

Berdasarkan latar belakang masalah tersebut maka perlu adanya pembaharuan dalam pelaksanaan pembelajaran terutama penggunaan media pembelajaran. Media pembelajaran dapat dikatakan sebagai alat bantu pembelajaran, yaitu segala sesuatu yang dapat dipergunakan untuk merangsang pikiran, perasaan perhatian, dan kemampuan atau ketrampilan peserta didik sehingga dapat mendorong terjadinya proses belajar.Seperti yang diungkapkan oleh Gagne dan Briggs (1975) secara implisit mengatakan bahwa media pembelajaran meliputi alat yang secara fisik digunakan untuk menyampaikan isi materi pembelajaran yang terdiri buku, tape recorder, kaset, video, kamera, film, slide (gambar bingkai), foto gambar, grafik, televisi, dan komputer.Hal ini dipertegas Nuryati (dalam Rini Rahmawati:20) yang menyatakan bahwa media adalah seegala sesuatu yang dapat menyalurkan pesan, yang dapat merangsang pikiran, perasaan,dan kemauan siswa sehingga mendorong terjadinya proses belajar pada dirinya.Penggunaan beberapa media dalam pembelajaran harus sesuai dengan materi yang ada. Adapun materi yang dibahas dalam penelitian kali ini adalah "Menulis Teks Eksplanasi". Agar materi mudah dipahami olleh peserta didik maka perlu penyajian dengan menggunakan media yang tepat yaitu Media Audio Visual.Dengan Media Audio Visual maka akan memberi peseerta didik waktu yang lebih banyak berpikir dan saling membantu satu sama lain sehingga peserta didik lebih aktif dalam pembelajaran. Dengan harapan pembelajaran dapat berpengaruh positif terhadap hasil belajar yang dicapai oleh peserta didik.

Perumusan masalah dalam penelitian ini adalah sejauh mana peserta didik aktif saat mengikuti proses pembelajaran, apakah peranan Media Audio Visual dapat meningkatkan motivasi menulis teks eksplanasi pada peserta didik kelas XII MIPA 1 SMA Negeri 1 
Gemolong dan apakah penerapan Media Audio Visual dapat meningkatkan kemampuan menulis teks eksplanasi pada peserta didik kelas XI MIPA 1 SMA Negeri 1 Gemolong. Adapun manfaat yang dapat diambil dari penelitian ini bagi peserta didik dapat meningkatkan keaktifan / motivasi peserti didik Sedangkan bagi guru memberikan alternatif media pembelajaran yang lain bagi guru Bahasa Indonesia untuk meningkatkan kemampuanny, serta bagi sekolah dapat meningkatkan kualitas sekolah melalui peningkatan motivasi dan kemampuan peserta didik dan kinerja guru.

Sudah banyak sekali para ahli psikologi pendidikan dan psikologi perkembanggan yang membahas tentang motivaasi dalam pembelajaran. Sedemikian banyaknya pembahasan tentang motivasi dalam pembelajaran itu telah menghasilkan definisi motivasi yang banyak pula. Namun demikian pada intinya motivasi dapat diartikan sebagai (1) Dorongan yang timbul pada diri seseorang scara disadari atau tidak disadari untuk melakukan suatu tindakan dengan tujuan tertentu. (2) Usaha-usaha yang dapat menyebabkan seseorang atau kelompok orang tertentu tergerak melakukan sesuatu karena ingin mencapai tujuan yang ingin dicapai, (Mohammad Asrori, 2007). Mulyasa (dalam Giyono, 2019:3) mengatakan bahwa motivasi adalah tenaga pendorong penarik yang menyebabkan adanya tingkah laku ke arah suatu tujuan tertentu. Peserta didik akan bersungguh-sungguh karena memiliki motivasi yang tinggi. Seorang siswa akan belajar bila ada faktor pendorongnya yang disebut motivasi.

Ketrampilan menulis merupakan salah satu jenis ketrampilan berbahasa yang harus dikuasai oleh siswa.Menurut Henry Guntur Tarigan (2001:15) menulis diartikan sebagai kegiatan menuangkan ide atau gagasan dengan menggunakan bahasa tulis sebagai media penyampaiannya.Lebih lanjut ia mengatakan bahwa menulis berarti mengekspresikan gagasan, ide, pendapat, atau pikiran dan meletakkan simbol grafis yang mewakili bahasa yang dimengerti orang lain. Eric Gould, Robert Di Yanni, dan William Smith (1999:18) mengungkapkan menulis merupakan suatu kreatifitas karena membutuhkan pemahaman dalam sebuah pengalaman, tulisan, dan peristiwa. Effendy (2008:327) berpendapat bahwa menulis adalah kegiatan interaksi antar individu dengan menggunakan bahasaDari pendapat para ahli tersebut, dapat disimpulkan bahwa menulis merupakan kegiatan menggali pikiran dan perasaan mengenai suatu subyek, memilih hal hal yang akan dituli, menentukan cara menuliskannya sehingga pembaca dapat memahami dengan mudahmdan jelas.

Kata media berasal dari bahasa latin medius yang secara harfiah berarti tengah, perantara, atau pengantar. Secara lebih khusus, pengertian media dalam proses belajar mengajar cenderung diartikan sebagai alat - alat grafis, potografis, atau elektronik untuk menangkap, memproses, dan menyusun kembali informasi visual atau verbal. Menurut Muhsidi (2015:28) mengatakan bahwa ketercapaian pembelajaran dipengaruhi oleh beberapa komponen diantaranya adalah metode pembelajaran yang tepat dan penggunaan media yang sesuai dengan karakteristik materi pembelajaran. Dalam Muhidi (2015:28) mengemukakan bahwa dalam metodologi pengajaran ada dua aspek yang paling menonjol yakni metode mengajar dan media pembelajaran sebagai alat bantu mengajar.

Sudjana dan Rivai (1992:2) mengemukakan manfaat media pembelajaran dalam proses belajar siswa yaitu : (1) Pembelajaran lebih menarik perhatian siswa sehingga 
dapat menumbuhkan motivasi belajar. (2) Bahan pembelajaran akan lebih jelas maknanya sehingga dapt lebih dipahami oleh siswa dan memungkinnya menguasai dan mencapai tujuan. (3) Metode mengajar akan lebih bervariasi tidak semata - mata komuniksi verbal melalui penuturan kata - kata oleh guru, sehingga siswa tidak bosan dan guru tidak kehabisan tenaga apalagi kalau guru mengajar pada setiap jam pelajaran. (4) Siswa dapat lebih banyak melakukan kegiatan belajar sebabtidak hanya mendengarkan uraian gur, tetapi juga aktivitas lain seperti mengamati, melakukan, mendemonstrasikan, memerankan dan lain-lain. Hamalik (Sumardi, 2020) mengungkapkan bahwa pemakaian media pembelajran dalam proses belajar mengajar dapat membangkitkan keinginan dan minat yang baru, membangkitkan motivasi dan rangsangan kegiatan belajar, dan bahkan membawa pengaruh psikologis terhadap siswa.

Media Audio Visual merupakan jenis media yang mengandung unsur suara juga mengandung sisual. Misalnya rekaman video, film, dan slide suara Kemampuan media inilebih baik dan lebih menarik, sebabselain mengandung unsur gambar yang bisa dilihat, misalnya rekaman video, berbagai ukuran film, dan slide, media ini juga mengandung unsur suara. Sesuai dengan pendapat Haryoko (2009:2) menerangkan bahwa media Audio Visual merupakan media penyampai informasi yang memiliki karakteristik audio (suara) dan visual (gambar). Sehingga siswa memiliki pengalaman sendiri secara langsung. Media Audio Visualjuga memiliki banyak kelebihan dan sedikit kekurangan dibanding media lainnya. Adapun beberapa kelebihandan kekurangan tersebut menurut beberapa sumber adalah sebagai berikut kelebihan mediaaudio vistual gerak/film yaitu: 1). film dapat menggambarkan suatu proses, misalnya proses pembuatan suatu keterampilan tangan dan sebagainya; 2) dapat menimbulkan kesan ruang dan waktu; 3). penggambarannya bersifat tiga dimensional; 4) suara yang dihasilkan dapat menimbulkan realita pada gambar dalam bentuk ekspresi murni, (5) dapat menyampaikan suara seorang ahli sekaligus melihat penampilannya; 6) kalau film dan video tersebut berwarna akan dapat menambah realita objek yang diperagakan;7) dapat menggambarkan teori sains dan animasi. Kekurangan media audio visual gerak/film yaitu:1) film bersuara tidak dapat diselingi dengan keterangan-keterangan yang diucapkan sewaktu film diputar, penghentian pemutaran akan mengganggu konsentrasi audiens; 2) audiens tidak akan dapat mengikut dengan baik kalau film diputar terlalu cepat; 3) apa yang telah lewat sulit untuk diulang kecuali memutar kembali secara keseluruhan; 4) biaya pembuatan dan peralatannya cukup tinggi dan mahal.

Sanjaya (2012:109) berpendapat mengenai keuntungan menggunakan media Audio Visual, yaitu: 1) dapat memberikan pengalaman belajar yang tidak mungkn dapat dipelajari secara langsung;2)memungkinkan belajar lebih bervariatif sehingga dapat menambah motivasi dan gairah belajar, 3) dapat berfungsi scbagai sumber belajar secara mandiri tanpa sepenuhnya tergantung pada kehadiran guru

Kerangka berpikir dalam penelitian ini dapat diterangkan sebagai berikut: kondisi awal tindakan dilaksanakan, diperoleh gambaran )yang dilaksanakan pada kegiatan prasurvei dengan observasi, wawancara, dan angket) bahwa dalam pembelajaran menulis teks eksplanasi yang berlangsung di SMA Negeri 1 Gemolong, (1) nilai kemampuan menulis teks eksplansi masih rendah, (2) guru menggunakan metode ceramah tanpa media dalam menyampaikan materi sehingga peserta didik kurang aktif dalam pembelajaran, (3) peserta didik kurang tertarik atau kurang senang dengan materi pelajaran teks eksplanasi . Dari kondisi ini peneliti mencoba menawarkan pembelajaran dengan menggunakan Media Audio Visual. 
Penggunaan media ini guru melakukannya dalam tiga tahap. Tahap pertama persiapan, pada tahap ini guru membuat rencana pelaksanaan pembelajaran, mempelajari buku petunjuk penggunaan media, dan menyiapkan peralatan media yang akan digunakan. Tahap kedua penyajian, pada tahap ini guru mengarahkan siswa mengamati dan mencatat materi yang penting, tanya jawab mengenai apa yang diamati, siswa menjelaskan lebih lanjut materi pelajaran. Tahap ketiga tindak lanjut, pada tahap ini aktivitas dilakukan untuk memantapkan pemahaman siswa tentang materi yang telah di sampaikan menggunakan Media Audi Visual. Untuk lebih jelasnya tentang kerangka berpikir pada penelitian ini dapat dilihat pada gambar berikut:

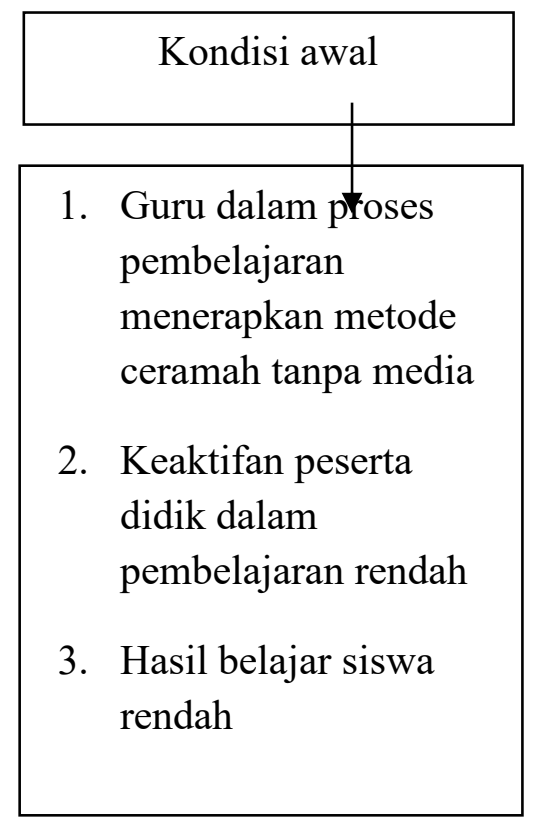
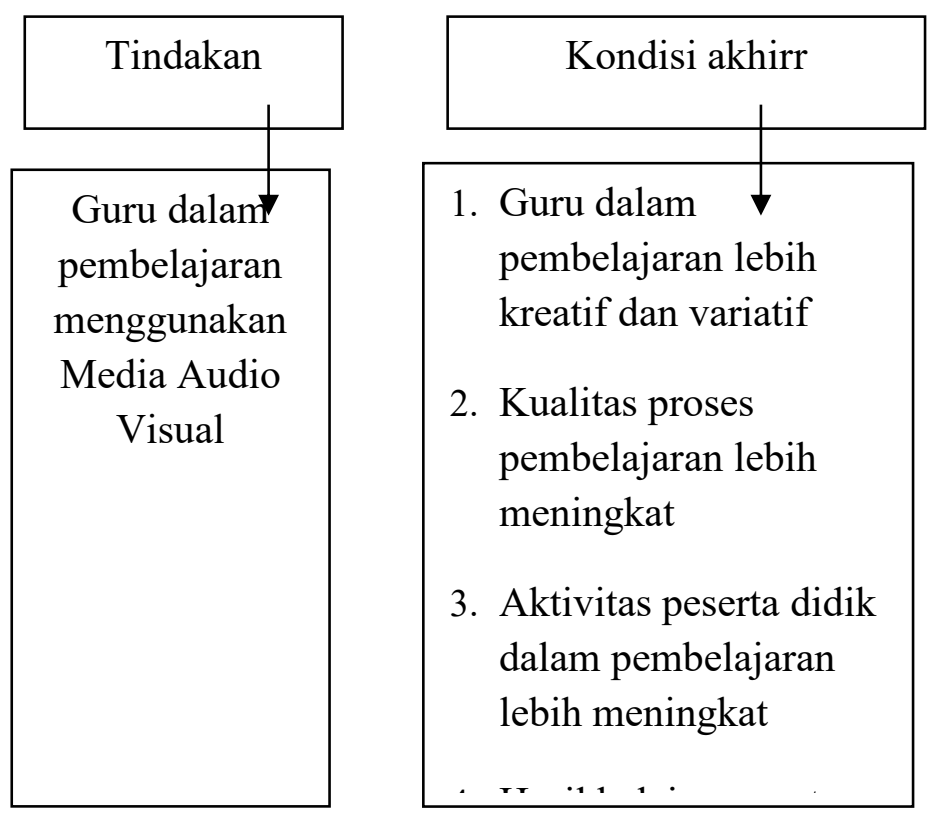

Gambar 1. Kerangka Berpikir

Berdasarkan kajian teoritis dan kerangka berpikir, maka hipotesisi penelitian ini dapat dirumuskan sebagai berikut: 1)Penggunaan Media Audio Visual dapat meningkatkan ketertarikan peserta didik selam pembelajaran. 2) Penggunaan Media Audio Visual dapat meningkatkan motivasi peserta didik selam pembelajaran. 3) Penggunaan Metode Audio Visual dapat meningkatkan kemampuan peserta didik selama pembelajaran.

\section{Metode Penelitian}

Penelitian ini merupakan penelitian tindakan kelas (PTK). Penelitian ini dilakukan di SMA Negeri 1 Gemolong. Kelas yang digunakan untuk penelitian tindakan kelas yakni kelas XI MIPA 1. lnformasi subjek yang digunakan dalam penelitian ini adalah Jumadi, S.Pd, selaku guru bahasa lndonesia dengan siswa kelas XI MIPA 1 berjumlah 36 orang. Pemilihan subyek menggunakan purposive sampling didasarkan atas keterampilan menulissiswa yang dinilaimasih rendah Prosedur Peneliti malakukan Penelitian Tindakan Kelas ini dengan langkah - langkah sebagai berikut : (1) persiapan (2) studi/survei awal (3) 
pelaksanaa siklus, dan (4) penyusunan laoran pelaksanaan siklus. Pelaksanaa siklus meliputi (a) perencanaan tindakan (planing), (b) pelaksanaan tindakan (acting), (c) pengamatan (obseerving), (d) refleksi (reflecting).

Tahap perencanaan tindakan (planning). Pada tahap ini, peneliti mengidentifikasi dan menetapkan masalah. Kemudian mengajukan suatu alternatif penggunanaan Media Audio Visual dalam mengatasi permasalahan dalam pembelajaran menulis. Selanjutnya, peneliti menyajikan data yang telah dikumpulkan kemudian bersama guru menentukan solusi yang tepat berdasarkan masalah yang dihadapi kemudia peneliti dan guru menyusun Rencana Pelaksanaan Pembelajaran (RPP) Bahasa Indonesia sesuai dengan silabus yang telah disusun oleh guru. Setelah itu, peneliti bersama guru merancang skenario pembelajaran menulis teks eksplanasi dengan menerapkan Meadia Audio Visual. Terakhir peneliti dan guru menyusun sistem penilaan yangmeliputi penilaian proses dan hasil dengan mengacu pada teori-teori yang relevanpelaksanaan tindakan (acting). Tahap ini berupa penerapan Media Audio Visual agar dapat meningkatkan motivasi belajar dan hasil ketrampilan menulis siswa dalam pembelajaran menulis teks eksplansi. Setiap tindakan yang dilakukan tersebut selalu diikuti dengankegiatan pemantauan dan evaluasi serta analisis dan refleksi. Dalam tahap ini peneliti melakukan observasi untuk mengetahui apakah tindakan yang dilakukan telah dapat mengatasi permasalalahan yang ada. Selain itu, peneliti juga melakukan observasi untukmengumpulkan data yang akan diolah untuk mengetahui segala kelemahan yang mungkin muncul. Data yang telah dikumpulkan tersebut diolah untuk menentukan tindakan penelitian berikutnya. Tahap penelitian berikutnya adalah tahap observasi (observing). Tahap ini dilakukan untuk memonitor tindakan yang terjadi di dalam kelas. Pada tahap ini, peneliti mengadakan obsevassi sebagai partisipan pasif peneliti berada di dalam lokasi penelitian. Namun demikian, tidak berperan aktif dalam kegiatan yang berlangsung.Setelah itu, peneliti mengadakan diskusi dengan guru lain mengenai hasil pengamatan peneliti. Dalam forum diskusi tersebut diungkapkan kelbihan dan kelemahan proses pembelajaran yang berlangsung dengan memfokuskan pada penampilan guru di kelas dan respons siswa terhadap dorongan guru.. Setelah data terkumpul, peneliti mengolah data tersebut hingga dapat disajikan pada guru agar dapat dicari solusi untuk berbagai permasalahan yang muncul. Tahapanalisis dan refleksi (reflecting). Tahap ini dilakukan untuk menganalisis hasil evaluasi. Kemudian, dianalisis untuk menentukan langkah-langkah langkah-langkah perbaikan apa yang dapat ditempu sehingga didapatkan suatu solusi semua permasalahan yang dialami oleh guru dan siswa dalam proses pembelajaran menulis. Pada tahap ini, peneliti menganalisis atau mengolah data yang telah dikumpulkan kemudian menyajikannya dalam pertemuan dengan guru yang bersangkutan. Setelah berdiskusi, diambil kesimpulan yang berupa hasil daripelaksanaan penelitian. Hasil penarikan kesimpulan ini dapat diketahui apakahpenelitian ini berhasil atau tidak sehingga dapat ditentukan langkah selanjutnya.

\section{Hasil Penelitian dan Pembahasan}

Sebelum melaksanakan tindakan, peneliti melakukan observasi untuk melihatketerampilan menulis teks eksplanasi siswa. Hasil penilaian dari lembar penilaian menulisteks eksplanasi yang diberikan oleh guru, jumlah siswa yang nilainyaberada rentang nilai 60-64 ada 11 siswa,yang nilainya masuk pada rentang nilai 65-69 ada 15 siswa,yang nilamya masuk rentang nilai $70-74$ ada 3 siswa. Yang nilainya masuk rentang nilai 75-79 ada 5 orang. Dan rentang nilai 80 ke atas 2 siswa. Aspek yang menjadi dasar 
penilaian guru adalah isi, organisasi isi originalitas, pemilihan kosakata, dan pengembangan bahasa.Dengan demikian, dapat disimpulkan bahwa 80,77\% siswa memiliki siswa dibawah KKM, yaitu75. Rendahnya nilai rata-rata serta hanya7 Siswa dari 36 siswa yang mampumemperoleh $\geq 75$ Adapun gambaran nilai - nilai peserta didik adalah sebagai berikut:

Tabel 1. Nilai Kondisi Pra Siklus

\begin{tabular}{clc}
\hline No & Uraian & Tes Awal \\
\hline 1 & Nilai $60-64$ & 11 siswa \\
2 & Nilai $65-69$ & 15 siswa \\
3 & Nilai $70-74$ & 3 siswa \\
4 & Nilai $75-79$ & 5 siswa \\
5 & Nilai 80 & 2 siswa \\
6 & Ketidaktuntasan & $80,77 \%$ \\
\hline
\end{tabular}

Berdasrkann data tersebut menunjukkan bahwa keterampilan menulis teks eksplanasi siswa rendah. Oleh karena itu, peneliti dan guru membuat rancangan pembelajaran guna mengatasi permasalahan tersebut. Dari rancangan yang telah dibuat maka peneliti melaksanakan siklus 1 .

Siklus I dilaksanakan pada hari Selasa, 12 April 2019. Setiap pertemuan terdiridari 2 x 45 menit (dua jam pelajaran). Langkah-langkah yang dilakukan pada siklus I pertemuan I sebagai berikut; Pertama, Siswa dibagi ke dalam kelompok heterogen baik dari segigender maupun kompetensi dengan Jumlah anggota 4-5 orang, Siswa diminta untukmenunjuk seorang ketua yang mengatur jalannya diskusi kelompok dan sekretaris yang menulis hasil diskusi. Setelah dibentuk menjadi 6 kelompok, guru mulai mengarahkan masing-masing siswa di dalam kelompoknya. Kedua. guru memberikan materi berupa penjelasandefinisi, struktur, jenis teks eksplanasi, serta perbedaannya dengan teks deskripsi. Ketiga,guru memutarkan sebuah video yang berisi tujuh topik berbeda, kemudian memintamasingmasing ketua kelompok memilih salah satu topik kemudian mengamati danmenjabarkan struktur teks eksplanasi di dalamnya. Keempat, guru mengamati proses diskusi kelompok siswa dan mengamati peran masing-masing Siswa. Guru berusaha mengarahkansiswa supaya saling bertukar pendapat atau memberikan masukan jawaban di dalam masingmasing kelompok sehingga sikap sosial siswa dapat berkembang. Guru memberikanarahan kepada kelompok yang mengalami kesulitan. Kelima, guru menginstruksi kepada perwakilan masing-masing kelompok untuk mempresentasikan hasil diskusi ke depankelas, kemudian guru memberikan kesempatan kepada siswa lain yang inginmemberikan tanggapan kepada kelompok yang sedang presentasI. Hal ini dilakukan untukmencocokkan jawaban antara kelompok satu dengan kclompok laimnya. Keenam,memberikan feedback atau umpan balik tetang pembelajaran yang sudah didapatkanguru. Guru menyampaikan kesimpulan atas materi yang sudah dilaksanakan siswadiperbolehkan menanyakan hal yang masih belum dimengerti Selanjutnya gurumemberikan ulasan pembelajaran untuk menyamakan persepsi tentang materi yang sudahdidiskusikan. Ketujuh, guru memberikan evaluasi untuk dikerjakan siswa secara individu sebisa mungkin guru melakukan penilaian Sikap ketika proses evaluasi sedangberlangsung Jika ada sikap siswa yang provokatif guru harus menegur supaya siswakembali fokus kepada tujuan belajar. Kemudian guru memberikan batasan waktumengerjakan kepada siswa, Jika dalam waktu yang sudah 
ditentukan ternyata masihbanyak siswa yang belum selesai, guru memberikan tambahan waktu mengerjakan \pm 10 menit. Kedelapan, guru memberikan reward kepada kelompok terbaik yang dilihat dari keaktifan, ketertiban dan kerjasama anggota kelompoknya. Rewarddapat berupa point tambahan nilai Selanjutnya guru memberikan motivasi kepada seluruh siswa untiuk terusmeningkatkan prestasi belajar supaya mendapatkan reward dalam pembelajaran selanjutnya. Gurumemberikan apresiasi dengan menggali pengalaman siswa dalam teks eksplanasi. Guru bertanya tentang pengalaman pribadi siswa melihat atau menemui teks eksplanasi langsung di masyarakat. Pada saat ini siswa mulai antusias menjawab pertanyaan gurukarena pertanyaan tersebut merupakan hal yang pernah dialami oleh siswa, Guru menguatkan Pengertian teks eksplanasi dan menjelaskan ciri-ciri, struktur dan aspek kebahasaan teks eksplanasi. Hal terscbut disambut biasa karena materi tersebut sering djelaskan sebelumnya.Perhatian siswa mulai terfokus kembali saat guru menugaskan siswa untuk membentuk kelompok diskusi dengan jumlah siswa 3-4 orang per kelompok. Kemudian guru mulai menerangkan langkah- langkah pembelajaran dengan menggunakan media Audio Visual"7Fenomena Alam Unik dan Aneh di Dunia Hal ini membuat perhatian siswa meningkatSeluruh Siswa menyimak video yang diputarkan dengan seksama. Kemudian, guru menyuruhsiswa berkelompok untuk berdiskusi untuk mengidentifikasi struktur kebahasaan dari contohteks eksplanasi dalam video dan mengembangkan sendiri teks eksplanasi dengan temaseperti video yang telah diberikan guru untuk hasil akhirnya guru menugaskanperwakilan siswa dari tiap kelompok untuk mempresentasikan hasil kerja kelompoknya. Selama proses pembelajaran pada siklus yang sudahsecara langsung di depan kelas.menerapkan media pembelajaran Audio Visual, siswa sudah terlihat tertarik pada pembelajaranmenulis teks eksplanasi. Siswa terlihat antusias mengikuti pembelajaran, hal ini terlihat darisiswa yang bersungguh-sungguh memperhatikan penjelasan guru. Tidak seperti padaobservasi awal. Namun masih ada pula siswa yang masih sibuk dengan urusannya sendiri,Jikaseperti mengobrol dengan teman sebangku, melamun, dan asik bermain sendiri. Dilihat dari kriteria yang telah ditetapkan maka, dapat dikatakan bahwa siklus I belumberhasil karena peningkatan rata-rata ketuntasan nilai keterampilan menulis teks eksplanasiditunjukkan rerata kelas adalah 74,61 dengan nilai tertinggi 90 dan nilai terendah 60,Jumlah siswa yang masih belum tuntas sebanyak 13 anak setara dengan 36\% dan yangsudah tuntas sebanyak 23 anak atau setara dengan 66\% Hal ini meunjukkan setidaknyaterdapat peningkatan keterampilan menulis teks eksplanasi siswa. Adapun gambaran nilai - nilai peserta didik adalah sebagai berikut:

Tabel 2. Nilai kondisi Siklus II

\begin{tabular}{clc}
\hline No & Uraian & Tes Awal \\
\hline 1 & Nilai terendah & 60 \\
2 & Nilai tertinggi & 90 \\
3 & Nilai rata-rata & 74,61 \\
4 & Ketuntasan & $66 \%$
\end{tabular}

Dari refleksi siklus I, dilakukan perancangan kegiatan sebagai upaya perbaikan dari siklus I Oleh karena itu peneliti dan guru melaksanakan siklus II. Pada siklus II, langkah-langkah yang ditempuh guru sebagai berikut. Pertama, guru mengulas beberapa pekerjaan yang masih salah dalam pembelajaran selanjutnya, kemudian menunjukan beberapa kesalahan penulisan maupun format yang seringkali dilakukan oleh siswa. Selanjutnya guru mengulang materi mengenai teks eksplanasi, meliputi struktur, jenis, ciri-ciri, serta sedikit tambahan berupa kaidah penulisan dan tatabahasa yang seringkali digunakan secara tidak 
tepatoleh Siswa, Siswa harus memperhatikan penjelasan guru supaya dapat mengerjakan tugasdan evaluasi dengan benar. Siswa diharapkan dapat mengajukan pertanyaan mengenai materi pembelajaran yang dianggap kurang dipahami. Kedua, guru membagikan lembar kerja kepada siswa untuk mengerjakan tugas kelompok memahami struktur teks eksplanasi pada video “Kenapa Air Laut Rasanya Asin?”. Kelima, guru memberikan kesempatan kepada siswa untuk mengerjakan soal dalam lembar jawab sesuai video yang sudah mereka saksikan.Keenam, guru menunjuk salah satu siswa secara acak untuk membacakan hasilpekerjaannya di depan kelas, guru kemudian menyampaikan kesimpulan materi danmemberikan kesempatan siswa untuk bertanya atas hal-hal yang masih belum diapahami. Gurujuga memberi penguatan materi kepada siswa tentang pembelajaran yang baru saja berlangsung.Ketujuh, guru membagikan soal evaluasi untuk mengukur pemahaman siswa mengenaimateri yang telah disampaikan. Siswa mengerjakan soal evaluasi secara individu. Gurumelakukan penilaian selama proses mengerjakan evaluasi berlangsung, Jika ada Siswa yangsibuk sendiri, mencontek atau membuat gaduh guru segera menegur, Selanjutnya, gurumemberi batasan waktu kepada siswa agar siswa lebih disiplin dalam menyelesaikan soalevaluasi. Langkah terakhir, guru memberikan reward kepada siswayang paling aktif berupapenambahan nilai. Setelah itu, guru tidak lupa untuk memberikan motivasi kepada seluruh Siswa untuk meningkatkan prestasi sehingga pada pertemuan selanjutnya siswa bersemangatdalam mengikuti kegiatan pembelajaran bahasa Indonesia. Pelajaran dilanjutkan pada hari Rabu,27 April 2019.

Pada siklus II ini siswa terlihat lebih antusias dan percaya diri dalam mengerjakan pekerjaannya menulis teks eksplanasi secara individu. Dengan adanya penayangan videoeksplanasi oleh guru, selain itu hasil tulisan siswa juga lebih baik dalam segi penggunaan bahasa, ejaan, dan pemilihan diksi serta pengungkapan idenya. Motivasi belajar siswa selama pembelajaran menulis teks eksplanasi Juga terlihat mengalami Peningkatan yang signifikan. Mereka berpendapat bahwa pembelajaranmenulis teks eksplanasi yang sekarang menjadi lebih menarik dan tidak membosankan seperti pada pembelajaran berbicara sebelum menggunakan media Audio Visual. Pembelajaran lebih menyenangkan karena siswa diberikan bahan tontonan yang menarik dan menggugah motivasi belajar mereka. Mereka juga merasa bahwa kegiatan menulis adalah kegiatanyang menyenangkan dan tidak sulit seperti apa yang mereka rasakan sebelum tindakandilakukan. Berdasarkan hasil tes dari KD menulid teks eksplanasi hasil observasi dapat diketahui bahwa nilai terendah 69 , nilai tertinggi 93, sedangkan ketuntasan mencapai $90,63 \%$, nilai rata-rata kelas sebesar $85,03 \%$.

Dari uraiantersebut dapat dilihat adanya peningkatan motivasi belajar siwa dan hasil keterampilan menulis teks eksplanasi siswa. Pada kondisi awal, siswa yang tuntas hanya 27,23\%, kemudian pada siklusI meningkat menjadi $66 \%$. Pada siklus II mengalami peningkatan menjadi $85,03 \%$. Untuk lebih jelasnya dapat dilihat tabel berikut:

Tabel3 : Hasil Tes Siklus III

No Uraian Nilai




\begin{tabular}{llc}
\hline 1 & Nilai terendah & 69 \\
2 & Nilai tertinggi & 93 \\
3 & Nilai rata-rata & 85,03 \\
4 & Ketuntasan & $90,63 \%$ \\
\hline
\end{tabular}

\section{Simpulan dan Saran}

Penerapan media Audio Visualdapat meningkatkan motivasi belajar siswa dalampembelajaran menulis teks eksplanasi. Berdasarkan hasil penelitian mengenai penerapan media Audio Visual dalam meningkatkan kemampuan menulis teks eksplanasi siswa, diperolehbeberapa kesimpulan sebagai berikut: Penerapan media Audio Visual untuk meningkatkanketerampilan teks eksplanasi pada siswa kelas XI MIPA I SMA Negeri 1 Gemolong TahunPelajaran 2018 -2019 terbukti mengalami peningkatan Berdasarkan pengamatan yangdilakukan selama dua siklus menghasilkan persentase hasil observasi terhadap guru padasiklus 1 yaitu $71 \%$. Yang pada siklus II mengalami peningkatan sebanyak 2,44\% menjadi73,44\%. Selain observer mengamati pembelajaran yang dilaksanakan guru, observer mengamati pembelajaran yang dilaksanakan siswa. Berdasarkan pengamatan yang dilakukan selama dua siklus menghasilkan observasi rerata Siswa siklusI sebesar $67,25 \%$. Nilai hasil belajar siswa pada siklus II mengalami Peningkatan sebesar $10,87 \%$ menjadi $73,12 \%$. Pada siklus I hasil keterampilan teks eksplanasi sudah meningkat dibandingkan sebelum pelaksanaan tindakan. Nilai rata-rata keterampilan teks eksplanasi yang diperoleh adalah 74,61 dengan persentase ketuntasan $69,23 \%$. Hasil keterampilan teks eksplanasi siswa pada siklus II memperoleh rata-rala nilai 84,42 dengan persentase ketuntasan sebesar $88,46 \%$. Berdasarkan simpulan di atas. Peneliti mengajukan saran-saran sebagai berikut: Pertama, saran bagi guru: (1) Guru perlu mengembangkan pelaksanaan pembelajaran menulis teks eksplanasi dengan mediaAudio Visual sehingga dapat meningkatkan motivasi belajar dan hasil keterampilan menulis teks eksplanasi, (2) Guru sebaiknya sering memberikan motivasi kepada siswa agar memaksimalkan segala yang dimiliki untuk mendapatkan hasil maksimal, (3) Guru harustanggap terhadap berbagai hambatan yang dialami dalam proses pembelajaran dan berusaha untuk mengatasinya, (4) Guru harus membuat evaluasi dan sistem penilaian yangtepat untuk mengetahui keberhasilan proses belajar-mengajar. Kedua, saran bagi siswa: (1) Siswa harus menyadari bahwa pembelajaran teks eksplanasi dapat memberikan manfaat bagi, (2) Siswa sebaiknya lebih kritis dan terbuka terhadap hal-hal baru yang mereka peroleh sehingga mampu menunjang proses dan hasil belajar mereka di sekolah, (3). Sebaiknya siswa lebih aktif dan berani selama proses pembelajaran berlangsung dan siswa harus banyak berlatih berbicara dan tidak malu untuk meminta bantuan guru apabila menghadapi kesulitan belajar. Ketiga, bagi sekolah: (1) Pihak sekolah hendaknya menambah sarana dan prasarana untuk memfasilitasi guru dan siswa dalam proses pembelajaran menulis sehingga siswa lebih termotivasi dan tertarik untuk mengikuti pembelajaran menulis, (2) Pihak sekolah sebaiknya membuat kebijakan sebagai upaya meningkatkan profesionalisme guru, misalnya mengikut sertakan guru dalam forum-forum ilmiah seperti MGMP, seminar pendidikan, dan diklat dalam bidang pendidikan, (3) Pihak sekolah sebaiknya memotivasi guru untuk melakukan inovasi dalam pembelajaran misalnya dengan melakukan penelitian tindakan kelas disertai pemilihal model, metode, dan media yang tepat. 


\section{Daftar Rujukan}

Effendy,O.U. (2008). Dinamika Komunikasi. Bandung: PT Remaja Rosdakarya Erric

Gould, Robert D. Yanni, dan William Smith. (1989). Teaching by Principls. San Fraancisco: State University.

Gagne dan Briggs. (1975). Instruktional Technology. Foundations. Hillsddale: Lawrence Erlmaun Assciates, Pubilshe

Giyono. (2019). Penerapan Metode Group Investigation untuk Meningkatkan Motivasi dan Kemampuan Menganalisis teks Negosiasi Peserta Didik Kelas X MIPA 1 SMA Negeri 1 Gemolong 2018/2019. Jurnal Pendidikan, volume 28(1), hal: 1 - 6.

Jumadi. (2018). Peningkatan Keaktifan dan Kemampuan Menulis Teks Anekdot dengan Menggunakan Model Pembelajaran Make A Match pada Siswa Kelas X SMA. Jurnal Pendidikan, volume 27(3), hal: 201-210.

Muhsidi, (2015). Penggunaan CD Modul Interaktif untuk Meningkatkan Hasil Belajar Akuntansi Materi Jurnal Khusus pada Perusahaan Dagang bagi Siswa Kelas XII IPS 1 SMA Negeri Klego Semester I Tahun Pelajaran 2011/2012. Jurnal Pendidikan, volume 24(1), hal: 25-38.

Priyatni, E.T. (2014). Desain Pembelajaran Bahasa Indonesia dalam Kurikulum 2013. Jakarta: Bumi Aksara.

Rahmawati, Rini. (2019). Metode Numbered Heads Together (NHT) dengan Menggunakan media Puzzle untuk meningkatkan Keaktifan Belajar Siswa SMP MTA Gemolong. Jurnal Pendidikan, volume 28(1), hal: 17-30.

Sanjaaya,W. (2012). Strategi Pembelajaran Berorientasi Standar Proses Pendidikan. Jakarta: Kencana Prenada Media Group.

Sudjana dan Rivai. (1992). Media Pengajaran. Bandung: C.V. Sinar Baru Bandung.

Sumardi. (2020). Apakah Melalui Media Audio Visual dan Metode STAD (Student sTeams Achievement Division) dapat meningkatkan Motivasi dan Hasil belajar Bahasa Inggris (Knoledge and Writing Skill) Teks Recount Kelas X IPS 2 SMA Negeri 1 Gemolong Kabupaten Sragen Semester I Tahun Pelajaran 2016/2017. Jurnal Pendidikan, volume 29(1), hal: 21-36.

Suwarto, S. (2009). Pengembangan tes dan analisis hasil tes yang terintegrasi dalam program komputer. Jurnal Penelitian dan Evaluasi Pendidikan, 13(1), 40-56.

Suwarto, S. (2017). Pengembangan tes ilmu pengetahuan alam terkomputerisasi. Jurnal Penelitian dan Evaluasi Pendidikan, 21(2), 153-161. 